Article

\title{
Critical Rethinking of Critical Thinking: A Contribution of Critical Pedagogy in Facing the Challenges of $\mathrm{K}+12$
}

Franz Giuseppe F. Cortez

\begin{abstract}
This paper argues that the tradition of Critical Pedagogy can deepen and sharpen our understanding of critical thinking as one of the manifest aims of the new Philippine educational system $(\mathrm{K}+12$ system). Thus, it is a critical rethinking of critical thinking. The paper discusses first Critical Pedagogy. It further explains critical thinking as one of the manifest aims of education. Then, it reveals the underlying principle of this dominant understanding of critical thinking. Using the perspectives of Critical Pedagogy, the paper explains that critical thinking cannot be restricted to a one-dimensional meaning of simply being a set of logical and cognitive skills. Inherent to critical thinking is its political and social dimension.
\end{abstract}

Keywords: critical pedagogy, critical thinking, critical theory, $\mathrm{K}+12$ in Philippine education

\section{Introduction}

$\mathrm{I}$ n a conference sponsored by The Philosophical Association of the Philippines, one of the questions that was addressed is this: "What updates or upgrades to philosophical pedagogy, in whatever educational level, may be considered, formulated and implemented, given $\mathrm{K}+12$ and the new General Education Curriculum?"1 Through this paper, I participate in answering this question. My direct response is this: In updating our philosophical pedagogy, we may also consider what the tradition of Critical Pedagogy can contribute. Thus, I state my main problem as: How can Critical Pedagogy participate in a meaningful rethinking of our educational

${ }^{1}$ The Conference is entitled "Philosophy and the Challenges of $\mathrm{K}+12$." It was held on 1-4 April, 2014 at San Pablo Seminary, Baguio City, Philippines. This article is a revised version of a paper presented on the said conference.

(C) 2016 Franz Giuseppe F. Cortez http://www.kritike.org/journal/issue 18/cortez june2016.pdf ISSN 1908-7330 
philosophy following the recent development in the Philippine educational system? I propose the following thesis statement: Critical pedagogy can deepen and sharpen our understanding of critical thinking as one of the manifest aims of the new Philippine educational system. In other words, through the lens of Critical Pedagogy, we can critically rethink critical thinking. The idea is not to offer a solution to an admittedly distressing problem in Philippine education. Rather, it is to invite a persistent and rigorous reflection on the character and inherent potentiality of a concept (that is, critical thinking) to emasculate on the one hand or to empower on the other hand.

To answer my main problem and to defend my thesis statement, I start with a discussion of Critical Pedagogy. I proceed to explain critical thinking as one of the manifest aims of education. Then, I show how the concept of "critical thinking" can be critically rethought. The last section is the concluding remarks.

\section{What is Critical Pedagogy?}

Some 30 years ago, in a monumental book entitled Theory and Resistance in Education (1983), the North American educator Henry A. Giroux coined the term "critical pedagogy" to refer primarily to an educational theory that is not just an obsession with criticizing the school as a production and reproduction mechanism, but is also a catalyst for opposition, resistance and change. ${ }^{2}$ Five years after, in his 1988 publication of Teachers as Intellectuals, Giroux used the terms "language of critique" and "language of possibility" to refer to the twin task of critical pedagogy - on the one hand, to problematize the school as a hegemonizing and homogenizing domain and on the other hand, to posit the school as a potential counter-hegemonic and counter-homogenizing force. ${ }^{3}$ He singles out Paulo Freire, a Brazilian educator and philosopher, as responsible for continuously highlighting this Janus-faced character of the school.

As the tradition of Critical Pedagogy evolves, it has become heterogeneous. Thus, Critical Pedagogy is not a monolithic discourse. According to Patricia Bizzell, a critical pedagogy scholar, critical pedagogy "should be taken to refer to a variety of practices, not one orthodox methodology." 4 Hence, rather than label it as Critical Pedagogy, we can talk

2 Henry A. Giroux, Theories and Resistance: Towards a Pedagogy for the Opposition (Connecticut: Bergin \& Garvey, 1983, c2001).

${ }^{3}$ Henry A. Giroux, Teachers as Intellectuals: Towards a Critical Pedagogy of Learning (Massachusetts: Bergin and Garvey, 1988), 108ff.

4 Patricia Bizzell, "Power, Authority and Critical Pedagogy," in Journal of Basic Writing, 10:2 (1991), 55.

(c) 2016 Franz Giuseppe F. Cortez http://www.kritike.org/journal/issue 18/cortez june2016.pdf ISSN 1908-7330

(c) $)$ BY-NC-ND 
of various critical pedagogies. But even if there are critical pedagogies, we can still find some commonalities in their discourses. According to Monica McLean in her book Pedagogy and the University (2006), the common features of Critical Pedagogy are "critique of current conditions; a focus on transformation and emancipation; emphasis on the value-laden and political nature of education; and interest in culture, identity and subjectivity." ${ }^{5}$

Critical Pedagogy is an embodiment in the educative setting of the Frankfurt School critical theory. In other words, Critical Pedagogy is one among many applications and implementations of Critical Theory in the realm of educational process and theorizing. Giroux acknowledged the extensive contributions of the Frankfurt School critical theorists, such as, Theodor Adorno, Max Horkheimer and Herbert Marcuse in laying the foundations of Critical Pedagogy. ${ }^{6}$ Joe Kincheloe talks about how Critical Theory "forms as one of the foundations of Critical Pedagogy."7 P. Lather stresses that Critical Pedagogy is "a combination of Frankfurt School critical theory, Gramscian counter-hegemonic practice and Freirean conscientization." ${ }^{\prime}$ J.M. Gore similarly suggests that this discourse is "borrowed from Neo-Marxism, the Critical Theory of the Frankfurt School, and oppositional politics generally." 9

It is significant to mention the tradition of Critical Theory running through the veins of Critical Pedagogy and soaring over its fields. It is because inasmuch as the Frankfurt School critical theory was very much informed by Marxian thoughts, critical pedagogies are also inherently Marxist pedagogical philosophies and practices. In an essay that documents various Marxian perspectives on education, Douglas Kellner identifies the tradition of Critical Pedagogy as a direct legacy of Marxian educational viewpoints. Kellner suggests that the critical pedagogues' attempts to intertwine Marxist concept of class oppression with other contemporary faces of oppression in the realm of gender, race and culture among others have provided the promises of expanding and enriching Marxist perspectives. ${ }^{10}$

${ }^{5}$ Monica McLean, Pedagogy and the University: Critical Theory and Practice (New York: Continuum, 2006), 94

${ }^{6}$ Giroux, Theories and Resistance, $7 \mathrm{ff}$.

${ }^{7}$ Joe L. Kincheloe, Critical Pedagogy Primer, $2^{\text {nd }}$ ed. (New York: Peter Lang Publishing Inc., 2008), 45.

${ }^{8}$ P. Lather, "Post-Critical Pedagogies: A Feminist Reading," in Feminisms and Critical Pedagogy, ed. by C. Luke and J.M. Gore (New York: Routledge, 1992), 122. As cited in Stephen D. Brookfield, The Power of Critical Theory for Adult Learning and Teaching (New York: Open University Press, 2005), 323.

${ }_{9}$ J. M. Gore, The Struggle for Pedagogies: Critical and Feminist Discourses as Regimes of Truth (New York: Routledge, 1993), 109. As cited in Brookfield, The Power of Critical Theory, 323.

${ }^{10}$ Douglas Kellner, "Marxian Perspectives on Educational Philosophy: From Classical Marxism to Critical Pedagogy," in University of Los Angeles, California, 
But Critical Pedagogy does not deify the whole of Marxism. Martin Jay makes this clear in his Dialectical Imagination (1973) when he says that "[one] of the essential characteristics of critical theory from its inception had been a refusal to consider Marxism a closed body of received truths."11 Stephen Brookfield, a prominent figure in critical adult educational theory and practice, says that "though critical theory can be conceived as a constant conversation with Marx, it is not a simple replication of Marxism."12 For his part, the Italian Antonio Gramsci, an all-the-way Marxist and whose concept of hegemony has become a household term for the critical pedagogues, does not fail to counsel us about the temptation to fall into an idolatrous worship of Marx and Marxism. He observes rightly that Marxism "tends to become an ideology in the worst sense of the word, that is to say a dogmatic system of eternal and absolute truths." 13

One of the important articles of the Black American thinker, Cornel West, who is considered as a progenitor of critical pedagogy, is fittingly titled "The Indispensability Yet Insufficiency of Marxist Theory." In this article, which is actually a 1992 dialogue between West and the Hungarian philosopher Eva L. Corredor, West stresses that "Marxist theory and Marxist sensibility are both indispensable and inadequate, something to build on but also something to bring serious critique to bear on."14 In the same vein of considering both the relevance and insufficiency of Marx, Freire says that, "Marx is not a has-been. He continues to be, needing only to be reseen."15 The critical theorists and the critical pedagogues do not cease to reflect on the potentials and limits of Marxist thoughts and approaches.

Words such as these are meant to respond to what Peter McLaren would call as the students' and teachers' "knee-jerk Marxophobia."16 Brookfield explains McLaren's understanding of this irrational fear of the bearded man in these words: "Marxophobia holds that even to mention Marx is to engage in un-American behavior and by implication to support the

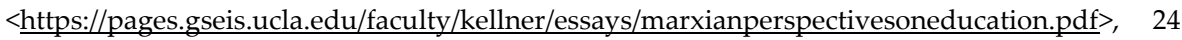
March 2012.

${ }^{11}$ Martin Jay, The Dialectical Imagination: A History of the Frankfurt School and the Institute of Social Research, 1923-1950 (Berkeley, CA: University of California Press, 1973), 254.

${ }^{12}$ Brookfield, The Power of Critical Theory, 19.

${ }^{13}$ Antonio Gramsci, Selections from the Prison Notebooks, ed. by Q. Hoare and G. N. Smith (London: Lawrence \& Wishart, 1971), 407.

${ }^{14}$ Cornel West, "The Indispensability Yet Insufficiency of Marxist Theory," in The Cornel West Reader (New York: Basic Civitas Books, 1999), 230.

${ }^{15}$ Paulo Freire, Pedagogy of Hope: Reliving Pedagogy of the Oppressed, trans. by Robert R. Barr (New York: The Continuum Publishing Corporation, 1995), 88.

${ }^{16}$ Peter McLaren, Life in Schools: An Introduction to Critical Pedagogy in the Foundations of Education, 3rd ed. (New York: Longman, 1997), 172.

(c) 2016 Franz Giuseppe F. Cortez http://www.kritike.org/journal/issue 18/cortez june2016.pdf ISSN 1908-7330

(c) $)$ BY-NC-ND 
genocide and repression exhibited by totalitarian communist regimes throughout history."17

The implication of this idea for us as Filipino educators is this. For those who think that by adopting Critical Pedagogy as one of the pedagogical philosophies relevant to the contemporary situation of Philippine education, one is turning the school into a haven of communists and NPAs, you can relax..$^{18}$ The reviewer of this paper opines that there is a difference between the academic appropriations of Marxism on the one hand and its use as an ideology for terrorism on the other hand. Moreso, by advocating some of the key features of critical pedagogy, we are not called to be fixated and obsessed with radical social restructuring through violent means. We neither expect the laborers nor incite the students to storm the Malacañang. Neither can we imagine the NPAs springing from the Cordillera Mountains and occupying every embodiment of power asymmetries in the lowlands. Following the line of thought of Paulo Freire, power must be redefined, reinvented and rediscovered. ${ }^{19}$

\section{Critical Thinking: An Educational Aim}

As always and as ever, the framers of Philippine educational system would never miss a magical phrase in the expression of our educational foundation. That phrase is "critical thinking," the crowning glory of humanist liberal education. As early as 2010, during a Department of Education (DepEd) discussion on the goals of $\mathrm{K}+12$, the following was already explicitly stated:

Every graduate of the Enhanced $\mathrm{K}+12$ Basic Education Program is an empowered individual who has learned, through a program that is rooted on sound educational principles and geared towards excellence, the foundations for learning throughout life, the competence to engage in work and be productive, the ability to coexist in fruitful harmony with local and global communities, the capability to engage in autonomous critical thinking, and the capacity to transform others and one's self. ${ }^{20}$

\footnotetext{
${ }^{17}$ Brookfield, The Power of Critical Theory, 19.

${ }_{18}$ NPA is New People's Army, the armed group of the Communist Party of the Philippines.

${ }^{19}$ Paulo Freire \& Antonio Faundez, Learning to Question: A Pedagogy for Liberation (New York: The Continuum Publishing Corporation, 1989), 63ff.

20 "Discussion Paper on the Enhanced K+12 Basic Education Program: DepEd Discussion Paper," October 5, 2010. Emphasis mine.
} 
After some time, the $\mathrm{K}+12$ Primer released by the Department states categorically that $\mathrm{K}+12$ is designed to develop a learner who, among others, "engages in critical thinking and creative problem solving." 21 This is what the framers of the new educational system refer to as producing "holistically developed learners with $21^{\text {st }}$ century skills." 22

I can safely assume that nobody will object to this. Various scholars even in opposing camps would agree that one of the noble aims of education is the development of critical thinking. Robin Barrow, in his book The Philosophy of Schooling (1981), declares that "one clear goal of education is developing powers of critical thought." 23 Even the Philippine Constitution's provision on education directly asserts that all educational institutions shall "encourage critical and creative thinking." 24 Furthermore, the vision-mission statement of many educational institutions does not fail to include "critical thinking" as one of the desired educational ends. It is one of those skills that every school would like to develop in its students. It is one of those proficiencies that every employer would be happy to find in the products of the educational institutions. Indeed, "critical thinking" has become an educational buzzword especially after the 1980 recommendation of the Rockefeller Commission on the Humanities, stating that critical thinking must be included by the U.S. Office of Education as one of the defining characters of true education. ${ }^{25}$ This has led Robert Sternberg, a prominent theorist of intelligence, to declare that: "Probably never before in the history of educational practice has there been a greater push to teach children to think critically." 26

But what do people mean by critical thinking? What do we understand when we say that we want our students to become critical thinkers? What does the dominant educational discourse mean by this statement? As we now enter a new chapter in the history of Philippine educational system, it is also high time to rethink what we mean by "critical thinking."

\footnotetext{
${ }^{21}$ Department of Education (Philippines), "K-12 Primer," in Rex Publishing House Philippines - Teachers' Lounge, < http://www.rexpublishing.com.ph/basiceducation/teacherslounge/basic-education/k-to-12-Primer/>, 19 December 2013.

${ }^{22}$ Ibid.

${ }^{23}$ Robin Barrow, The Philosophy of Schooling (Brighton: Wheatsheaf Books, 1981), 45. As cited in Periklis Pavlidis, "Critical Thinking as Dialectics: A Hegelian-Marxist Approach," in Journal of Critical Education Policy Studies, 8:2 (2010), 78.

${ }^{24}$ The 1987 Constitution of the Republic of the Philippines, Art. XIV, Sec. 3, No. 2.

25 Robert H. Ennis, "Critical Thinking and the Curriculum," in Thinking Skills Instruction: Concepts and Techniques, ed. by Marcia Heiman and Joshua Slomianko (Washington, D.C.: National Education Association, 1987), 40.

${ }^{26}$ Robert Sternberg, "Teaching Critical Thinking: Are We Making Critical Mistakes?" in Thinking Skills Instruction, 209.
}

(c) 2016 Franz Giuseppe F. Cortez http://www.kritike.org/journal/issue 18/cortez june2016.pdf ISSN 1908-7330 


\section{Critical Rethinking of Critical Thinking}

To start a critical rethinking of critical thinking, we must be aware that we do not have a univocal understanding of this term. Faculty members attending a seminar on curriculum development may all nod their heads when somebody proposes that the development of "critical thinking" is a must. But I highly suspect if the polite head-nodding signifies a uniform and standardized understanding of the term. According to Jennifer Moon, critical thinking "seems to be a prominent activity in education ... but about which there is so much uncertainty." 27 She calls it "an elusive concept." 28

The second step in this process of rethinking involves asking the question: What is the dominant understanding of critical thinking as an educational goal? Barrow says that critical thinking includes coherent reasoning, conceptual clarity, discrimination in planning, discussion, explanation and others. ${ }^{29}$ Diane Halpern mentions a review of literature on critical thinking which shows the following as some of its main features: "reasoning/logic, judgment, metacognition, reflection, questioning and mental processes." ${ }^{30}$ Stella Cottrell lists the following as some of the skills and attitudes of a critical thinker: "identifying other people's positions, arguments and conclusions; identifying false and unfair assumptions; drawing conclusions about whether arguments are valid and justifiable, based on good evidence and sensible assumptions." ${ }^{31}$ Nicholas Burbules and Rupert Berk further observe that this tradition of critical thinking is primarily concerned with "criteria of epistemic adequacy: to be 'critica' basically means to be more discerning in recognizing faulty arguments, hasty generalizations, assertions lacking evidence, truth-claims based on unreliable authority, ambiguous or obscure concepts and so forth." 32 It is clear from these various explanations that critical thinking is basically a mental process. Irvin Peckham calls this the cognitive strand of the critical thinking tradition. He says that, "teachers in the cognitive strand focus on argumentation as the exclusive vehicle of critical thought." ${ }^{33}$

\footnotetext{
${ }^{27}$ Jennifer Moon, Critical Thinking: An Exploration of Theory and Practice (London: Routledge, 2008), 3.

${ }^{28}$ Ibid., 19.

${ }^{29}$ Barrow in Pavlidis, "Critical Thinking as Dialectics," 45.

${ }^{30}$ Diane F. Halpern, Thought and Knowledge: An Introduction to Critical Thinking, $4^{\text {th }}$ ed. (New Jersey: Lawrence Erlbaum Associates, 2003), 6.

31 Stella Cottrell, Critical Thinking Skills: Developing Effective Analysis and Argument (New York: Palgrave Macmillan, 2005), 2.

${ }^{32}$ Nicholas Burbules and Rupert Berk, "Critical Thinking and Critical Pedagogy: Relations, Differences and Limits," in Critical Theories in Education, ed. by Thomas S. Popkeweitz and Lynn Fendler (New York: Routledge, 1999), 46.

${ }^{33}$ Irvin Peckham, Going North, Thinking West: The Intersections of Social Class, Critical Thinking, and Politicized Writing Instruction (Utah: Utah State University Press, 2010), 12.
} 
The third step in this rethinking is to ask the question: What is the philosophical foundation of this dominant understanding of critical thinking? Brookfield's study of the different traditions of critical thinking offers a worthwhile answer. In a book entitled The Power of Critical Theory for Adult Learning and Teaching (2005), he suggests that the notion of criticality in critical thinking can be traced to at least five different traditions: analytic philosophy, pragmatism, psychoanalysis, constructivism and critical theory. ${ }^{34}$ Brookfield further suggests that the tradition of logic and analytic philosophy has dominated the educational underpinning of higher education. He says: "From this perspective, to be critical is to be skilled at argument analysis, to recognize false inferences and logical fallacies, to be able to distinguish bias from fact, opinion from evidence, and so on." 35 I can further assume that the most concrete manifestation in our educational system of the dominance of this critical thinking tradition is the long-standing habitation of Logic as a philosophy subject offered in many tertiary educational institutions and in some secondary schools. ${ }^{36}$

This leads me to the next step in this rethinking: Given that there is a notion of critical thinking privileged in many academic institutions, what is marginalized along the way? Again, Brookfield's observation is very helpful. He believes that the skills developed by the analytic tradition are useful and necessary but the tradition's overemphasis on mental processes has led to inattention to social and political critique. ${ }^{37}$ Peckham calls this the social strand of critical thinking, which is concerned with promoting social justice. He says: "The critical thinking within this strand is not a function of informal logic and language; rather, it applies to a way of reading culture, of demystifying or denaturalizing socializing narratives." 38 The development of the skills of reasoning and argumentation is not done for itself. Rather, it is privileged "for the larger purpose of promoting social justice." 39

And here lies the significance of the tradition of Critical Theory in general and Critical Pedagogy in particular. The critical teacher is concerned not only with the validity of reasoning process. Pedagogy must involve a deeper understanding of the socio-political and economic arrangements that hegemonize and homogenize the lives of the students. This is partially what Freire would mean by conscientization, an educational process that prepares

\footnotetext{
${ }^{34}$ Brookfield, Preface to The Power of Critical Theory, viii.

${ }^{35}$ Ibid.

${ }^{36}$ In the current curriculum, philosophy subjects are not anymore centered on Aristotelian Logic but on Philosophy of the Human Person and Introduction to World Religions. I consider this a welcome development. Future researchers may also consider the history of the dominance of Logic as a philosophy subject in the Philippine educational system.

${ }^{37}$ Brookfield, Preface to The Power of Critical Theory, vii.

${ }^{38}$ Peckham, Going North, Thinking West, 12.

${ }^{39} \mathrm{I} b i d ., 12$.

(c) 2016 Franz Giuseppe F. Cortez http://www.kritike.org/journal/issue 18/cortez june2016.pdf ISSN 1908-7330
} 
students to become skillful not only in reading the word (both traditional literacy and functional literacy) but also in reading the world (critical and political literacy). ${ }^{40}$ By themselves, functional literacy and traditional academic skills cannot remedy the marginalized status of the citizens. Literacy must involve a continual demystification of socio-economic and political forces responsible for the oppressive condition of the people. It is worthwhile to quote in full one of Freire's most concrete description of a conscienticized individual.

A person who has reached conscientization is capable of clearly perceiving hunger as more than just not eating, as the manifestation of political, economic, and social reality of deep injustice ... [He/she] is able to connect facts and problems and to understand the connections between hunger and food production, food production and agrarian reform, agrarian reform and reactions against it, hunger and economic policy, hunger and violence and hunger as violence, hunger and the conscious vote for progressive politicians and parties, hunger and voting against reactionary politicians and parties, whose discourse may be deceptively progressive..$^{41}$

Thus, critical thinking is a fusion of various literacies. Relevant education is not reduced to what is acclaimed in the workforce or in the corporate world or by students and parents themselves: technicism and instrumentalism. ${ }^{42}$ Relevance comes to mean also as dynamic participation in democratic processes and citizenship. ${ }^{43}$ It is the substitution of a culture of

${ }^{40}$ Freire discusses these ideas in many of his works. The following are good starting points: Pedagogy of the Oppressed (1968), The Politics of Education: Culture, Power, and Liberation (1985), and one co-authored with Donaldo Macedo, Literacy: Reading the Word and Reading the World (1987).

${ }^{41}$ Paulo Freire, Letters to Cristina: Reflections on My Life and Work, trans. by Donaldo Macedo, Quilda Macedo, and Alexandre Oliveira (New York: Routledge, 1996), 182-183.

42 "We submit to the peaceful production of the means of destruction, to the perfection of waste, to being educated for a defense which deforms the defenders and that which they defend." Herbert Marcuse, Introduction to One-Dimensional Man: Studies in the Ideology of Advanced Industrial Society (London: Routledge, c1991), xxxix.

${ }^{43}$ In an article, Beatrice Avalos argues that relevance in education must be understood in the Habermasian sense. It must satisfy not only the technical and practical interests of an individual or a society but also the emancipatory interests. See Beatrice Avalos, "Education for the Poor: Quality or Relevance" in British Journal of Sociology of Education, 13:4 (1992), 431.

(C) 2016 Franz Giuseppe F. Cortez http://www.kritike.org/journal/issue 18/cortez june2016.pdf

ISSN 1908-7330 
voice to what Freire would call as a culture of silence. ${ }^{44}$ As we prepare our students to land their first job, we also prepare them to learn to question. In fact, this is clear in the $\mathrm{K}+12$ agenda: education is not only for job preparation but for total human development. Critical pedagogues take seriously statements such as this.

But of course, my ideas are neither groundbreaking nor earthshaking for Philippine education. Some Filipino scholars do not fail to remind us of the necessity of this dimension of critical thinking. Let me just mention some. Renato Constantino's "Miseducation of the Filipino," originally written in 1959, is a critique of the neocolonial character of our educational system. ${ }^{45}$ I do not buy the idea that it has ceased to become relevant after more than half a century. In a 1971 paper, Fernando NakpilZialcita reminds Filipino scholars to allow philosophy as a critique of the society to flourish and develop along with other forms of philosophizing. ${ }^{46}$ Thirty-two years after, Feorillo Demeterio III, in at least two articles, calls for Filipino scholars of philosophy to learn again the pathway of critique understood not just as logical thinking but as critique of our deformed societal structures as well. ${ }^{47}$ Even in a 1995 publication, Florentino Hornedo emphatically says that values education in the Philippines must necessarily be education for social justice. ${ }^{48}$ And I am sure that I am missing many more.

Admittedly, when educators commit to this notion of critical thinking, they may be treading on inhospitable and dangerous ground: putting their profession at risk, gaining the ire of the powers-that-be, held under suspicion by school administrators and co-faculty members, frowned by students and parents who see the school merely as a training ground for careerism. Freire was very much aware of this dilemma of the critical teacher. In one of his dialogical books, he says that the teacher must be able to play around the system: one foot outside and one foot within the system. ${ }^{49}$

\footnotetext{
${ }^{44}$ For his discussion on the notion of culture of silence, see Paulo Freire, "Cultural Action and Conscientization," in Freire, The Politics of Education, 67ff.

${ }^{45}$ Renato Constantino, "The Mis-education of the Filipino," in The Filipinos in the Philippines and Other Essays (Quezon City: Filipino Signatures, 1966).

${ }^{46}$ Fernando Nakpil-Zialcita, "Mga Anyo ng Pilosopiyang Pilipino," trans. by Nicanor G. Tiongson, in Mga Babasahin sa Pilosopiya: Epistemolohiya, Lohika, Wika at Pilosopiyang Pilipino, ed. by Virgilio Enriquez (Manila: Philippine Psychology Research and Training House, 1983), 321.

${ }^{47}$ F.P.A. Demeterio III, “Thought and Socio-Politics: An Account of the Late Twentieth Century Filipino Philosophy," in HINGOWA: The Holy Rosary Seminary Journal, 8:2 (2003), 47. See also F.P.A. Demeterio III, "Defining the Appropriate Field for Radical Intra-State Peace Studies in Filipino Philosophy," in Philippiniana Sacra, 38:13 (2003), 358.

${ }^{48}$ Florentino H. Hornedo, Christian Education: Becoming Person-for-Others - Essays in Philosophy of Education (Manila, UST Publishing House, 1995), 150.

49 Paulo Freire and Ira Shor, A Pedagogy for Liberation: Dialogues on Transforming Education (Connecticut: Bergin \& Garvey Publishers, Inc., 1987).
}

(c) 2016 Franz Giuseppe F. Cortez http://www.kritike.org/journal/issue 18/cortez june2016.pdf ISSN 1908-7330 
Stephen Sweet, a Sociology professor from the State University of New York, recognizes the institutional constraints; thus, he argues for balancing and tempering radical pedagogy by being conscious and considerate about these constraints. ${ }^{50}$ Giroux's words are also enlightening. Citing the former City University of New York (CUNY) Chancellor, Joe Murphy, he says that educators should "give students [the critical] sensibility to understand economic, political, and historical forces so they're not just victims of these forces but can act on them with effect. Giving [students, especially the poor] this power is a threatening idea to many. But it is essential to the health of a democratic society." 51

\section{Concluding Remarks}

Personally, notwithstanding the preparedness (or unpreparedness?) of the Philippine government and its citizenry, I recognize the fact that the major re-structuring of Philippine education $(\mathrm{K}+12$ system) is a progressive move in the continuous evolution of the concept that education is a privilege gifted to a few into the "modern" idea that it is a fundamental human right for each person. ${ }^{52}$ The former basic education system is at best a right that is wanting. At worst, it is a privilege that disguises itself as a right. The present one is in the direction of the actualization of a right. $\mathrm{K}+12$ is a progressive one step forward.

However, in the interest of total human development being bannered by the new educational system in the Philippines, we have to listen as well to the critical pedagogues. When critical thinking is rethought critically, we will find out that it means more than what majority of the framers of our new educational system would like it to mean as a $21^{\text {st }}$ century skill. It cannot be confined to a one-dimensional meaning of simply being a set of logical skills. Inherent to critical thinking is its political and social dimension. ${ }^{53}$ To be critical is also to have the skill to problematize dominant knowledge and to

\footnotetext{
50 Stephen Sweet, "Practicing Radical Pedagogy: Balancing Ideals with Institutional Constraints," in Teaching Sociology, 26:2 (1998), 100-111.

${ }^{51}$ Henry A. Giroux, "Cultural Studies as Public Pedagogy: Making the Pedagogical More Political," in Encyclopaedia of Educational Philosophy and Theory (October 1999),

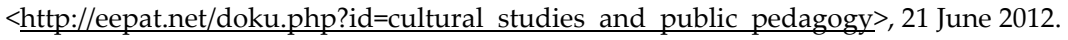

${ }^{52}$ Cf. C. Lohrenscheit, "Curriculum and Human Rights," in. International Encyclopedia of Education, vol. 1, ed. by Penelope Peterson, Eva Baker, Barry McGaw (Oxford: Academic Press, 2010), 287.

${ }^{53}$ In another book, Stephen Brookfield claims that "critique" is a sacred word. And it cannot be understood properly when separated from the tradition of Frankfurt School Critical Theory. See Stephen D. Brookfield, "Transformative Learning as Ideology Critique," in Learning as Transformation: Critical Perspectives on a Theory in Progress, ed. by Jack Mezirow \& Associates (San Francisco, California: Jossey-Bass, 2000), 129.
} 
challenge hegemonic arrangements. We have to make the critical in critical thinking more critical. ${ }^{54}$ Anything less is merely lip-service.

Then, when we look at the new $\mathrm{K}+12$ curriculum, we will also find out that the field of philosophy, arguably a deathbed discipline that is in dire need of resuscitation,, 55 is in a better position to reclaim and reintroduce the critical in critical thinking. Edukasyon sa Pagpapakatao, the values-education subject given to students across all year levels in the new Basic Education, and Introduction to the Philosophy of the Human Person, obviously a philosophy subject required for senior high school students to take, are exciting venues and avenues for critical pedagogues. In the first place, Logic as the main takeoff for critical thinking skill is already abolished. Secondly and more importantly, the two courses mentioned have the potential to support teaching and learning for social justice and equality. I have the inkling that these subjects have a temper that is in harmony with what Freire would call as "reading the word" and "reading the world." Who in their right minds can accept the fact that pagpapakatao may not involve concern for justice, equality and human rights? Pagpapakatao is always a dynamic tension between personal agency and social agency. Freire is correct once again: Education is always Janus-faced! There will always be cracks and openings for the critical educators to operate. Philosophy is both a force for domestication and/or liberation.

The tradition of Critical Pedagogy and Critical Theory offers interesting and promising signposts for this noble but extremely difficult undertaking. The idea is not to replace one tradition with the other. Rather, Critical Pedagogy extends the discourse. And by extending it, at least two things are accomplished. First, the dominant discourse on critical thinking is problematized, for this concept can really be appropriated to cater to the interest of the dominant part of the society. ${ }^{56}$ The "critical thinker" becomes an effective $\operatorname{cog}$ in the well-oiled machine of an oppressive system. Second, the marginalized discourse is given a place in the vast field of what Agustin Rodriguez, in his book Governing the Other (2009), would term as "multiverse

${ }^{54}$ Joe L. Kincheloe, "Making Critical Thinking Critical," in Perspectives in Critical Thinking: Essays by Teachers in Theory and Practice, ed. by D. Weil and H.K. Anderson (New York: Peter Lang, 2000).

${ }^{55}$ For accessible but provocative insights on the demise of philosophy as an academic discipline, see Lee McIntyre, "Making Philosophy Matter-Or Else," in The Chronicle of Higher Education (11 December 2011), < $\underline{\text { http://chronicle.com/article/Making-Philosophy-Matter- }}$ or/130029/>, 11 March 2014.

${ }^{56}$ Michael Payne \& Jessica Rae Barbera, "Some Versions of Cultural and Critical Theory," in A Dictionary of Cultural and Critical Theory, $2^{\text {nd }}$ ed., ed. by. Michael Payne and Jessica Rae Barbera (West Sussex, UK: Wiley-Blackwell, 2010), 8.

(c) 2016 Franz Giuseppe F. Cortez http://www.kritike.org/journal/issue 18/cortez june2016.pdf ISSN 1908-7330

(c) BY-NC-ND 
of rationality." 57 We need different perspectives on education. We cannot just submit to one dominant discourse.

In the spirit of Freirean liberating education, I ask you not to just accept what I said here but to think critically about it. ${ }^{58}$

Department of Philosophy, University of Santo Tomas, Philippines

\section{References}

Avalos, Beatrice, "Education for the Poor: Quality or Relevance" in British Journal of Sociology of Education, 13:4 (1992).

Bizzell, Patricia, "Power, Authority and Critical Pedagogy," in Journal of Basic Writing, 10:2 (1991).

Brookfield, Stephen D., The Power of Critical Theory for Adult Learning and Teaching (New York: Open University Press, 2005).

"Transformative Learning as Ideology Critique," in Learning as Transformation: Critical Perspectives on a Theory in Progress, ed. by Jack Mezirow \& Associates (San Francisco, California: Jossey-Bass, 2000).

Burbules, Nicholas \& Rupert Berk, "Critical Thinking and Critical Pedagogy: Relations, Differences and Limits," in Critical Theories in Education, ed. by Thomas S. Popkeweitz, \& Lynn (New York: Routledge, 1999).

Constantino, Renato, "The Mis-education of the Filipino," in The Filipinos in the Philippines and Other Essays (Quezon City: Filipino Signatures, 1966).

Cottrell, Stella, Critical Thinking Skills: Developing Effective Analysis and Argument (New York: Palgrave Macmillan, 2005).

Demeterio, F.P.A. III., “Defining the Appropriate Field for Radical Intra-State Peace Studies in Filipino Philosophy," in Philippiniana Sacra, 38:13 (2003).

"Thought and Socio-Politics: An Account of the Late Twentieth Century Filipino Philosophy," HINGOWA: The Holy Rosary Seminary Journal, 8:2 (2003).

“Discussion Paper on the Enhanced K+12 Basic Education Program: DepEd Discussion Paper," October 5, 2010.

Department of Education (Philippines), "K-12 Primer," in Rex Publishing House Philippines - $\quad$ Teachers' Lounge, $<\underline{\text { http://www.rexpublishing.com.ph/basic- }}$

\footnotetext{
${ }^{57}$ Agustin Martin Rodriguez, Governing the Other: Exploring the Discourse of Democracy in a Multiverse of Reason (Quezon City: Ateneo de Manila University Press, 2009).

${ }^{58}$ Paulo Freire, "Reading the World and Reading the Word: An Interview with Paulo Freire," in Language Arts, 62:1 (1985), 24-29.
} 
education/teacherslounge/basic-education/k-to-12-Primer/>,

December 2013.

Ennis, Robert H., "Critical Thinking and the Curriculum," in Thinking Skills Instruction: Concepts and Techniques, ed. by Marcia Heiman and Joshua Slomianko (Washington, D.C.: National Education Association, 1987).

Freire, Paulo and Antonio Faundez, Learning to Question: A Pedagogy for Liberation (New York: The Continuum Publishing Corporation, 1989).

Freire, Paulo and Ira Shor, A Pedagogy for Liberation: Dialogues on Transforming Education (Connecticut: Bergin \& Garvey Publishers, Inc., 1987).

Freire Paulo, Letters to Cristina: Reflections on My Life and Work, trans. by Donaldo Macedo, Quilda Macedo, and Alexandre Oliveira (New York: Routledge, 1996). Pedagogy of Hope: Reliving Pedagogy of the Oppressed, trans. by Robert R. Barr (New York: The Continuum Publishing Corporation, 1995).

"Reading the World and Reading the Word: An Interview with Paulo Freire," in Language Arts, 62:1 (1985).

Giroux, Henry A., "Cultural Studies as Public Pedagogy," in Encyclopaedia of Educational Philosophy and Theory (1999), < http://eepat.net/doku.php?id=cultural studies and public pedagog $\mathrm{y}>, 21$ June 2012.

Teachers as Intellectuals: Towards a Critical Pedagogy of Learning (Massachusetts: Bergin and Garvey, 1988).

Theories and Resistance: Towards a Pedagogy for the Opposition (Connecticut: Bergin \& Garvey, 1983, c2001).

Gramsci, Antonio, Selections from the Prison Notebooks, ed. by Q. Hoare and G. N. Smith (London: Lawrence \& Wishart, 1971).

Halpern, Diane F., Thought and Knowledge: An Introduction to Critical Thinking, $4^{\text {th }}$ ed. (New Jersey: Lawrence Erlbaum Associates, 2003).

Hornedo, Florentino H., Christian Education: Becoming Person-for-Others Essays in Philosophy of Education (Manila, UST Publishing House, 1995).

Jay, Martin, The Dialectical Imagination: A History of the Frankfurt School and the Institute of Social Research, 1923-1950 (Berkeley, CA: University of California Press, 1973).

Kellner, Douglas, "Marxian Perspectives on Educational Philosophy: From Classical Marxism to Critical Pedagogy," in University of Los Angeles, California, <https://pages.gseis.ucla.edu/faculty/kellner/essays/ marxianperspectivesoneducation.pdf $>$, 24 March 2012.

(c) 2016 Franz Giuseppe F. Cortez http://www.kritike.org/journal/issue 18/cortez june2016.pdf ISSN 1908-7330 
Kincheloe, Joe L., Critical Pedagogy Primer, $2^{\text {nd }}$ ed. (New York: Peter Lang Publishing Inc., 2008). "Making Critical Thinking Critical," in Perspectives in Critical Thinking: Essays by Teachers in Theory and Practice, ed. by D. Weil and H.K. Anderson (New York: Peter Lang, 2000).

Lohrenscheit, C., "Curriculum and Human Rights," in. International Encyclopedia of Education, vol. 1, ed. by Penelope Peterson, Eva Baker, Barry McGaw (Oxford: Academic Press, 2010).

Marcuse, Herbert. One-Dimensional Man: Studies in the Ideology of Advanced Industrial Society (London: Routledge, c1991).

Lee McIntyre, "Making Philosophy Matter-Or Else," in The Chronicle of Higher Education (11 December 2011), <http://chronicle.com/article/ Making-Philosophy-Matter-or/130029/>, 11 March 2014.

McLaren, Peter, Life in Schools: An Introduction to Critical Pedagogy in the Foundations of Education, 3rd ed. (New York: Longman, 1997).

McLean, Monica, Pedagogy and the University: Critical Theory and Practice (New York: Continuum, 2006).

Moon, Jennifer, Critical Thinking: An Exploration of Theory and Practice (London: Routledge, 2008).

Nakpil-Zialcita, Fernando, "Mga Anyo ng Pilosopiyang Pilipino," trans. by Nicanor G. Tiongson, in Mga Babasahin sa Pilosopiya: Epistemolohiya, Lohika, Wika at Pilosopiyang Pilipino, ed. by Virgilio Enriquez (Manila: Philippine Psychology Research and Training House, 1983).

Pavlidis, Periklis, "Critical Thinking as Dialectics: A Hegelian-Marxist Approach," in Journal of Critical Education Policy Studies, 8:2 (2010).

Payne, Michael \& Jessica Rae Barbera, "Some Versions of Cultural and Critical Theory," in A Dictionary of Cultural and Critical Theory, $2^{\text {nd }}$ ed., ed. by Michael Payne and Jessica Rae Barbera (West Sussex, UK: Wiley-Blackwell, 2010).

Peckham, Irvin, Going North, Thinking West: The Intersections of Social Class, Critical Thinking, and Politicized Writing Instruction (Utah: Utah State University Press, 2010).

Rodriguez, Agustin Martin, Governing the Other: Exploring the Discourse of Democracy in a Multiverse of Reason (Quezon City: Ateneo de Manila University Press, 2009).

Sternberg, Robert, "Teaching Critical Thinking: Are We Making Critical Mistakes?" in Thinking Skills Instruction, ed. by Marcia Heiman and Joshua Slomianko (Washington, D.C.: National Education Association, 1987)

Sweet, Stephen, "Practicing Radical Pedagogy: Balancing Ideals with Institutional Constraints," in Teaching Sociology, 26:2 (1998).

The 1987 Constitution of the Republic of the Philippines.

(C) 2016 Franz Giuseppe F. Cortez http://www.kritike.org/journal/issue 18/cortez june2016.pdf ISSN 1908-7330 


\section{CRITICAL [RE]THINKING}

West, Cornel, "The Indispensability Yet Insufficiency of Marxist Theory," in The Cornel West Reader (New York: Basic Civitas Books, 1999). 